\title{
Criminality, Substance abuse and Problematic Family Relations in Adolescence
}

\author{
Valeria Saladino $^{1 *}$, Lilli Hoelzlhammer ${ }^{2}$ and Valeria \\ Verrastro ${ }^{3}$
}

'Department of Humanities, Social, and Health, University of Cassino and Southern Lazio, Cassino, Italy

2Department of Language and Literature, LMU Munich (Ludwig-Maximilians-Universität) Germany, Bavaria

${ }^{3}$ Department of Medical and Surgical Sciences, University of "Magna Graecia", Catanzaro, Italy

Received: 15 April, 2020
Accepted: 28 April, 2020
Published: 28 April, 2020

*Corresponding author: Valeria Saladino, PsyD, PhD Department of Humanities, Social, and Health, University of Cassino and Southern Lazio, Cassino, Italy, E-mail:v.saladino@unicas.it

Keywords: Adolescence; Substance abuse; Criminality; Family

https://www.peertechz.com

\section{Check for updates}

\section{Abstract}

Adolescence is characterized by high level of psychosocial vulnerabilities. It is a developmental phase in which youths explore themselves, others, and their social context. At the same time, the physical, behavioral and cognitive changes influence the self-image of adolescents. In addition, risk-taking and sensation-seeking are common and often associated with the engagement in risky or transgressive behaviors. During adolescence, aggressive conduct or use of substance may symbolise a need of control. Adolescents often behave aggressively to achieve their autonomy and self-identity from the family system. Criminological and developmental psychology's theories focus on these behaviors and consider individual, family and environmental factors from a multifactorial point of view. This brief article shows some considerations about the relationship between criminality, substance abuse and family system in youths' development.
\end{abstract}

\section{Introduction}

During adolescence there is an increasing possibility of becoming a perpetrator of violence or being involved in atrisk behaviors, such as drugs use and unlawful acts. Such behavioral difficulties burden families, schools, communities, and society at large. Substance abuse during adolescence is often associated with delinquency and aggressive conduct, which are common among adolescents who experience family conflict or parental neglect.

Delinquency and substance use could become habitual modes of conduct and communication for adolescents. The importance of the family system and parenting in this regard has been emphasized by several studies carried out in Europe, the United States, South America, Africa and Asia. They all conclude individually on the large impact of parental support and parenting style, parental drinking and incarceration on the youth's illicit and antisocial behavior and on substance use [13].

\section{Data on adolescents with risky behavior in considera- tion of their family structures}

To begin, an overview about various data collected on adolescents' risky behavior will be given. This will stress the significance of parents' presence and influence or lack thereof.

Data from the Youth Risk Behavior Surveillance [4], report that $11.1 \%$ of youths has been in a physical fight in school, and $5.6 \%$ has carried a weapon at least once in the past month and that one of the significant risk factors in their behaviors is family disruption. Analysing adolescents' focus-group data regarding their perceptions of violence and their coping strategies in managing conflict, emerged that they were aggressive mostly to protect family. Participants also used terms of endearment and possession to identify family membership, for instance, the term "my princess" referring to a cousin. They described their communities and lives as lacking in supports and safety, affirming that the use of violence is a strategy to survive. The adults in their lives were perceived as unable to protect and 
help them in avoiding fights. Most participants affirmed that their parents were absent all the time and that they did not provide any protection against others' violence. For some of the participants in the study, their mothers were perceived as protective against neighborhood violence. Additionally, this perception of the family involved an excess of responsibility and a lack of confidence, which affected the participants' interpersonal anger management skills.

Data from the National Longitudinal Study of Adolescent Health [5], confirm these results, reporting low-income family background as one of the primary predictor variables of early adolescent substance use. Participants who had unemployment parents and relationships with people involved in illegal acts, were more likely to perceive lower cohesion and safety in their social context and to experiment binge drinking and smoking marijuana.

On the other hand, participants who perceived their parents as more conscientious and present were less likely to engage in substance use and delinquent acts. Moreover, the use of drugs is not affected by social and individual risk factors whether the family is intact. Tucker and colleagues (Ibidem) examined the influence of family risk factors in the use of substances, assessing the following variables: low parental control, closeness to mother, availability of drugs at home, differentiating between alcohol and illegal drugs.

Regarding marijuana initiation, an intact family is a protective factor that is not associated to personal demographics, as gender, age and ethnicity; while binge drinking is associated with behavioral and family risk factors, such as the use of marijuana, delinquent behavior, low parental supervision, permissive or absent parents, and having alcohol readily available in the home. Moreover, these results show a difference between risk factors and type of substance: marijuana is more related to peers and linked to illicit activities, while binge drinking relates to the family system (opportunity to drink at home or parents who drink).

Additionally, adolescents who experienced these risk factors foresee few opportunities for themselves and have less hope for the future. Consequently, they may be at higher risk in drug selling and related activities. Along the same lines, the Northeast Communities Against Substance Abuse conducted a survey, involving rural and suburban communities and associating alcohol consumption with parental drinking. In fact, parental drinking seems to be associated with increased odds to become an alcohol experimenter, occasional polysubstance user, or frequent polysubstance user. At the same time, parental disapproval of substance use is associated with decreased odds to become a frequent polysubstance user compared to other users.

According to Canadian Institutes of Health Research and the Heart and Stroke Foundation of Canada the same results are valid for the use of marijuana [6]. Marijuana remains the most commonly used illicit drug among adolescents, frequently related to addiction, to the use of other illicit drugs (OID) and to delinquent and aggressive behaviors. As in alcohol users, frequent marijuana use is negatively related to parental support, as shown by a comparison between frequent lifetime marijuana users to never or less frequent lifetime marijuana users. Therefore, good relationships with parents may reduce the risk to develop an addiction or to use OID during adulthood.

The family system influences adolescents' risky behavior. Regarding to violence it has been shown that it is considered a form of communication, often connected to the perceived unreliability of adults. For substance abuse, there seems to be evidence that, although experiments with binge drinking and marijuana depend on different circumstances, an intact family system functions as a protective factor. Accordingly, it will be shown in the next paragraph how certain parenting styles affects teens' tendencies towards criminal behavior and substance abuse.

\section{Influence of different parenting styles on adolescent development}

According to the literature, each family is a dynamic system composed by a specific parenting style. The construct of parenting style, initially described by Baumrind in 1991 [7], is characterized in two dimensions: affection or responsiveness and control or demandingness, giving rise to four distinct categories: authoritarian style, authoritative style, indulgent style and negligent style [8].

Responsive parents are affective, empathic, and close. They pay attention to their children's lives, communicating affection and recognizing their achievement. Conversely, demandingness refers to control, severe education and enforcing to respect strict rules of behavior.

Based on this theory, parents with an authoritarian style report a low level of affection and a high level of control; authoritative style is characterized by a high level of both affection and control; indulgent style involves high affection but low control, and negligent style is characterized by low level of both affection and control.

Adolescents whose parents are authoritative are less likely to become heavy drinkers. They show more resilience, selfesteem and a better psychological adjustment. Additionally, authoritative parenting is negatively related to alcohol use even when adolescents have friends who drink [9].

Negligent parental style impairs self-regulation skills of youths, thus teenagers may develop problems of adaptation and functionality related to behavioral problems, or social competence [10-14]. A research on German students showed the relationship between negative parenting and aggressive conducts [15]; another research on Turkish adolescents emphasized the importance of perceived parenting on aggression and self-esteem $[16,17]$.

In contrast with these findings, some studies consider authoritarian parental style as a risk and indulgent style as a protective factor $[18,19]$ and show that adolescents who have authoritarian and authoritative parents appear more hostile than others, and that mother's deprivation, physical 
coercion, and mother's verbal coercion are the most significant predictors of hostility [19-22]. Also, data obtained from class analysis showed an inverse association between negligent parenting styles and alcohol users/binge drinkers, tobacco, marijuana and synthetic drugs [23]. However, the majority of findings identify authoritative style as a protective factor. Other studies focused on the differences between mother and father [24], found that mother is often more indulgent than father, who is more negligent.

Negligent father' style may involve externalization problems in teens more than the indulgent mother' style. Studying the association between fathers' and mothers' parenting style and externalizing behaviors, Groh, et al. [25], found that father's participation has a positive impact on the acquisition of empathy and social skills, factors related to lower rates of risky behaviors. The relevance of father's parental style was confirmed by a longitudinal study conducted by the Centre for Research into Parenting and Children, Oxford, United Kingdom. As noted in this study, father's involvement in the adolescent life plays a protective role in well-being of the adolescent. These findings are also associated with positive parent-adolescent relationship, and with a low level of aggressiveness [26].

In this line, the Baltimore Prevention Project [27], collected data from high school students and examined associations between incarcerated fathers (FEI) and substance use during adolescence for the US population; $13 \%$ of the sample had fathers in jail and this is associated with an increasing use of marijuana and OID, and higher levels of delinquency. Other outcomes suggested the positive correlation between father imprisonment and alcohol and marijuana use; $51.3 \%$ of males and $39.3 \%$ of females with FEI reported using marijuana, compared to $37.7 \%$ and $28.3 \%$ of males and females, respectively, without FEI. Father's imprisonment is not the only factor, but it is related to other factors of the family system, such as parental separation, poor parenting, history of physical abuse, maltreatment and parents' neglect, which are also associated with criminal involvement. Violence, abuses, and abandonment are more related with criminality during adolescence and adulthood than parental substance use.

The mother also plays an important role in adolescent life: National Longitudinal Study of Adolescent Health indeed reported that mother' binge drinking and demandingness could be a predictor of substance use in adolescence [28].

Finally, the most favorable situation for adolescents is to have support and involvement in their lives from both parents. Moreover, authoritative parenting style is associated with less conflict within the family and subsequent developmental adjustment for adolescents [12]. In late adolescence parentchild relationship gradually become less hierarchical and more horizontal, and teens need more emotional support from their parents. Hence, in this phase maternal and paternal support should focus on emotional regulation $[29,30]$. Based on the review of the literature, therefore, the important central aspect is the balance between affection and control and the role of father and mother in parenting: the father as the educator in social and normative skills and mother as a caregiver [31].
Additionally, attachment and sense of belonging to the family or surrogates like school, peers, and religious communities, mediate the use of violence. These aspects guarantee informal control during the transition to adulthood and reduce likelihood of future involvement in the legal system. Secure attachment and close relationship with parents decrease the rate of violence [32] and promote relational and social skills [33]. Adolescents with secure attachment show more confidence and better emotional regulation skills than adolescents with avoidant attachment, who have more difficulty in interpersonal relationships [34]

The role played by the father is essential for attachment and also as a predictor of adolescent' aggressive conducts. The scientific literature highlights that family structure also influences behavior. Children who lived in mono-parental and dysfunctional family are more likely to fall into risky behavior during adolescence [35] than children who lived in an intact family. Data collected from 372 single-mother families showed that maternal responsiveness positively influences adolescent development as compared to "broken" homes and "deficiency" of single-mother families [36].

Similar results are common in adolescents who have good family' communication and disclosure [37]. This confidence facilitates emotional managing, problem-solving and coping skills, decreasing violent and risky acts [38].

Contrariwise poor communication involves an emotional gap, which may develop in risky behavior and parental drug talk styles in early adolescent may increase the use of substance in teens [39].

Parenting and children-parent relationship is important also in order to promote the development of self-control, aspect often involved in criminal and risky conducts.

\section{Crime and self-control: the importance of family edu- cation}

According to the well know General Theory of Crime by Gottfredson and Hirschi [40], criminal conduct derives from two elements: self-control and opportunity. The authors affirm that a reduced ability to self-control can leads to an increased probability of committing a crime when the opportunity in engaging the behavior is present [41].

The level of self-control in children is strongly influenced by the parenting style, and becomes stable during the development: children who grow up in neglected families are more likely in becoming deviant; while children who are educated according the values of support and respect of the rules, develop higher capacity of self-control. Low self-control is also characterized by some behavioral traits, such as impulsivity and risk taking, which are often associated to aggressive and criminal conducts. Thus, low self-control could be interpreted as a predictor of crime and of analogous behaviors [42].

Gottfredson and Hirschi (Ibidem) contend that a good parenting practices (e.g. monitoring, discipline and warmth) results in good self-control in children. Parents who educate 
their children to resist to easy gratification, supporting them, increase the possibility of their success in social institutions and interpersonal relationshipswhich require delay in gratification, tolerance of frustration and the acceptance of compromises [43]. Indeed, children who develop a good self-control are more likely to implement prosocial behaviors in adolescence and adulthood, avoiding criminal conduct.

Based on the general theory of crime and on the main studies on parenting styles, Li, et al. [44], focused their study on three categories of parenting: positive educational practices, negative educational practices, and parent-child relationships.

Their study described positive parenting as a balance between control and warmth, such as monitoring, supervision and support; negative parenting characterized by overprotection, hostility and coercive punishment, and parentchild relationships as children's bonds with their parents.

These parenting styles influence the development of selfcontrol and the relational skills of youths. For instance, positive parenting promotes close parent-child relationship and help parents in teaching self-control to their children $[45,46]$. In the same line, youth with good self-control are more likely in engaging socially desirable behavior and in listening their parents.

These results suggest the influence that parenting style has in youths' self-control and vice versa, underling the protective role of both, in behavioral problems and risky conducts of adolescents.

\section{Conclusion}

Taken together, these findings suggest that parental support, psychological control, and parental monitoring, attachment and communication are mediators in teen's risky behaviors, emphasizing the importance to promote parental skills in order to decrease negligent parenting.

It would be simplistic, however, to continue considering the relationship between parent and adolescent as a oneway street. Based on the most recent researches, it would be closer to reality the description of this relationship as coconstructed by parents and adolescents, as a circular system. It will therefore be necessary for future studies to collect data that considers the interplay of parents and adolescents in order to gain a better understanding of the causes and motivations behind adolescents' risky behavior.

\section{References}

1. Piko B, Balázs MÁ (2012) Authoritative parenting style and adolescent smoking and drinking. Addict Behav 37: 353-356. Link: https://bit.ly/35be2pK

2. Thomas RE, McLellan J, Perera R (2013) School-based programmes for preventing smoking. Cochrane Database Syst Rev 8: 30: CD001293. Link: https://bit.ly/3bLOS3w

3. World Health Organization (2011) WHO report on the global tobacco epidemic Genova World Health Organization. Link: https://bit.ly/3f1oPHt

4. Kann L, McManus T, Harris WA, Shanklin SL, Flint KH, et al. (2016) Youth Risk Behavior Surveillance - United States, 2015" Morbidity and Mortality Weekly Report: Surveillance Summaries 65: 1-174.
5. Tucker JS, Pollard MS, de la Haye K, Kennedy DP, Green HD, et al. (2013) Neighborhood characteristics and the initiation of marijuana use and binge drinking. Drug Alcohol Depend 128: 83-89. Link: https://bit.ly/3bJOZN7

6. De Looze M, Janssen I, Elgar FJ, Craig W, Pickett W (2015) Neighborhood crime and adolescent cannabis use in Canadian Adolescents. Drug Alcohol Depend 146: 68-74. Link: https://bit.ly/2xjw4d0

7. Tavassolie T, Dudding S, Madigan AL, Thorvardarson E, Winsler A (2016) Differences in Perceived Parenting Style Between Mothers and Fathers: Implications for Child Outcomes and Marital Conflict. J Child Fam Stud 25: 2055-2068. Link: https://bit.ly/2zvlcbo

8. Lei H, Chiu MM, Cui Y, Zhou W, Li S (2018) Parenting Style and Aggression: A Meta-Analysis of Mainland Chinese Children and Youth. Child Youth Serv Rev 94: 446-455. Link: https://bit.ly/3eZVg9e

9. Bahr SJ, Hoffmann JP (2010) Parenting Style, Religiosity, Peers, and Adolescent Heavy Drinking. J Stud Alcohol Drugs 71: 539-543. Link: https://bit.ly/3cPIgB6

10. Luk JW, Patock-Peckham JA, Medina MTN, Belton D, King KM, et al. (2016) Bullying perpetration and victimization as externalizing and internalizing pathways: A retrospective study linking parenting styles and self-esteem to depression, alcohol use, and alcohol-related problems. Subst Use Misuse 51 113-125. Link: https://bit.ly/3f8djua

11. Mestre MV, Tur A, Samper P, Latorre A (2010) Inestabilidad emocional y agresividad. Factores predictors [Emotional instability and aggressiveness. Predictive factors. Ansiedad y Estrés 16: 33-45.

12. Jiménez-Barbero J, Ruiz-Hernández AJ, Llor-Esteban $B$, Waschgler K (2016) Influence of attitudes, impulsivity, and parental styles in adolescents' externalizing behavior. J Health Psychol 21: 122-131. Link: https://bit.ly/3cZ4KzX

13. Tur-Porcar A, Mestre V, Samper P, Malonda E (2012) Crianza y agresividad de los menores: ¿es diferente la influencia del padre y de la madre? [Parenting and minors' aggressiveness: Is the influence of the father and the mother different?, Psicothema 24: 284-288. Link: https://bit.ly/2yNIIXq

14. Van der Watt R (2014) Attachment, parenting styles and bullying during pubertal years. J Child Adolesc Ment Health 26: 251-261. Link: https://bit.ly/2YebeH4

15. Hofer J, Spengler B (2108) How negative parenting might hamper identity development: spontaneous aggressiveness and personal belief in a just world. Self and Identity 19: 117-139. Link: https://bit.ly/3cVeV8s

16. Avcı E, Sak R (2018) The relationship between parenting styles and fourth graders' levels of empathy and aggressiveness. Current Psychology 38: 1-13. Link: https://bit.ly/3bIMtXe

17. Özdemir Y, Vazsonyi AT, Çok F (2017) Parenting processes, self-esteem, and aggression: A mediation model. Eur J Dev Psychol 14: 509-532. Link: https://bit.ly/3aNJ3Bg

18. Gracia E, Fuentes MC, Garcia F (2012) Perceived neighborhood violence, parenting styles, and developmental outcomes among Spanish adolescents. J Community Psychol 40: 1004-1021. Link: https://bit.ly/2yQ5V61

19. Martínez I, Fuentes MC, García F, Madrid I (2013) El estilo de socialización familiar como factor de prevención o riesgo para el consumo de sustancias y otros problemas de conducta en los adolescentes españoles. Family socialization style as a prevention or risk factor for substance consumption and other behavior problems in Spanish adolescents. Adicciones 25: 235-242. Link: https://bit.ly/3bMmoX

20. Aymerich MDM, Musitu G, Palmero F (2018) Family Socialization Styles and Hostility in the Adolescent Population. Sustainability 10: 29-62. Link: https://bit.ly/2VLeo3j

Citation: Saladino V, Hoelzlhammer L, Verrastro V (2020) Criminality, Substance abuse and Problematic Family Relations in Adolescence. J Addict Med Ther Sci 6(1): 016-020. DOI: https://dx.doi.org/10.17352/2455-3484.000031 
21. De la Torre-Cruz MJ, García-Linares MC, Casanova-Arias PF (2014) Relationship between parenting styles and aggressiveness in adolescents. Electron J Res Educat Psychol 12: 147-169. Link: https://bit.ly/2Y9aKIv

22. Trinkner R, Cohn ES, Rebellon CJ, Van Gundy K (2012) Don't trust anyone over 30: Parental legitimacy as a mediator between parenting style and changes in delinquent behavior over time. J Adolesc 35: 119-132. Link: https://bit.ly/2VMwZMx

23. Peña L, Blanco EIL, Pérez A, Morello P, Santillan EA, et al. (2017) Parental Style and Its Association with Substance Use in Argentinean Youth. Subst Use Misuse 52: 518-526. Link: https://bit.ly/3cY3n4C

24. Gómez-Ortiza O, Romera EM, Ortega-Ruiz R (2016) Parenting styles and bullying. The mediating role of parental psychological aggression and physical punishment. Child Abuse \& Neglect 51: 132-143. Link: https://bit.ly/3cUgPWT

25. Groh AM, Fearon RP, Bakermans-Kranenburg MJ, Van ljzendoorn MH, Steele $\mathrm{RD}$, et al. (2014) The significance of attachment security for children's social competence with peers: A meta-analytic study. Attachment and Human Development 16: 103-136. Link: https://bit.ly/2VKdmVm

26. Symeou M (2015) Parent control and parent-adolescent conflict as parameters of externalizing and internalizing behaviors: investigating the moderating effects of adolescents' psychopathic traits: Kúnрoc: University of Cyprus, Faculty of Social Sciences and Education. Link: https://bit.ly/2SfafCJ

27. Furr-Holden CD, Lee MH, Milam AJ, Johnson RM, Lee KS, et al. (2011) The growth of neighborhood disorder and marijuana use among urban adolescents: a case of policy and environmental interventions. J Stud Alcohol Drugs 72: 371-379. Link: https://bit.ly/2YbV3tG

28. Roettger ME, Swisher RR, Kuhl DC, Chavez J (2011) Paternal incarceration and trajectories of marijuana and other illegal drug use from adolescence into young adulthood: evidence from longitudinal panels of males and females in the United States. Addiction research Report 106: 121-132.

29. Riquelme M, García OF, Serra E (2018) Psychosocial maladjustment in adolescence: Parental socialization, self-esteem, and substance use. Annals of psychology 34: 536-544. Link: https://bit.ly/3bJZgJb

30. Van Lissa CJ, Keizer R, Van Lier P, Meeus WHJ, Branje S (2017) Emotion regulation in adolescence. The role of fathers versus mothers parenting in emotion-regulation development from mid-late adolescence: Disentangling between-family differences from within-family effects. Link: https://bit.ly/3eWnXE5

31. Gallarin M, Alonso-Arbiol I (2012) Parenting practices, parental attachment and aggressiveness in adolescence: A predictive model. J Adolesc 35: 1601 1610. Link: https://bit.ly/3bQLaWw

32. Cho S, Hong JS, Sterzing PR, Woo Y (2017) Parental Attachment and Bullying in South Korean Adolescents: Mediating Effects of Low Self-Control, Deviant Peer Associations, and Delinquency. Crime Delinq 63: 1168-1188. Link: https://bit.ly/3cT40kE

33. Groh AM, Fearon RMP, Van I Jzendoorn MH, Bakermans-Kranenburg $M$ Roisman JGI (2017) Attachment in the Early Life Course: Meta-Analytic
Evidence for Its Role in Socioemotional Development. Child Development Perspectives 11: 70-76. Link: https://bit.ly/2W47vZL

34. Clear SJ, Zimmer-Gembeck MJ (2017) Associations between Attachment and Emotion-Specific Emotion Regulation with and without Relationship Insecurity Priming. Int J Behav Dev 41: 64-73. Link: https://bit.ly/3bNPhSU

35. Wong SK (2017) The effects of single-mother and single-father families on youth crime: Examining five gender-related hypotheses. International Journal of Law Crime and Justice 50: 46-60. Link: https://bit.ly/2W0arqo

36. Leung JTY, Shek DTL (2018) Unbroken Homes: Parenting Style and Adolescent Positive Development in Chinese Single-Mother Families Experiencing Economic Disadvantage. Child Indicators Research 11: 441-457. Link: https://bit.ly/3aJUsC3

37. Savage J (2014) The association between attachment, parental bonds and physically aggressive and violent behavior: A comprehensive review. Aggress Violent Behav 19: 164-178. Link: https://bit.ly/3aLHyUj

38. Haverfield MC, Theiss JA (2017) Parental Communication of Responsiveness and Control as Predictors of Adolescents' Emotional and Behavioral Resilience in Families with Alcoholic Versus Nonalcoholic Parents. Human Communication Research 43: 214-236. Link: https://bit.ly/2W9xdMJ

39. Pettigrew J, Miller-Day M, Ju Shin Y, Krieger JL, Hecht ML, et al. (2018) Parental Messages about Substance Use in Early Adolescence: Extending a Model of Drug-Talk Styles. Health Commun 33: 349-358. Link: https://bit.ly/2YjZeUa

40. Gottfredson MR, Hirschi T (1990) A General Theory of Crime. Palo Alto California: Stanford University Press. Link: https://www.sup.org/books/ title/?id=2686

41. Fine A, Steinberg L, Frick PJ, Cauffman E (2016) Self-Control Assessments and Implications for Predicting Adolescent Offending. J Youth Adolesc 45: 701-712. Link: https://bit.ly/2W7qoLo

42. Vazsonyi AT, Pickering LE, Junger M, Hessing D (2001) An empirical test of a general theory of crime: A four-nation comparative study of selfcontrol and the prediction of deviance. J Res Crime Deling 8: 91-131. Link: https://bit.ly/3aJMbhB

43. Pratt TC, Cullen FT (2000) The empirical status of Gottfredson and Hirschi's general theory of crime: A meta-analysis. Criminology 38: 931-964. Link: https://bit.ly/2YeS4ke

44. Tangney JP, Baumeister RF, Boone AL (2004) High self-control predicts good adjustment, less pathology, better grades and interpersonal success. J Pers 72: .271-324. Link: https://bit.ly/2VHZYAU

45. Li JB, Willems YE, Stok FM, Deković M, Bartels M, et al. (2019) Parenting and Self-Control Across Early to Late Adolescence: A Three-Level Meta-Analysis. Perspect Psychol Sci 14: 967-1005. Link: https://bit.ly/2KF1k9h

46. Özdemir Y, Vazsonyi AT, Çok F (2013) Parenting processes and aggression: The role of self-control among Turkish adolescents. J Adolesc 36: 65-77. Link: https://bit.ly/2Sd689W

Copyright: (c) 2020 Saladino V, et al. This is an open-access article distributed under the terms of the Creative Commons Attribution License, which permits unrestricted use, distribution, and reproduction in any medium, provided the original author and source are credited.

Citation: Saladino V, Hoelzlhammer L, Verrastro V (2020) Criminality, Substance abuse and Problematic Family Relations in Adolescence. J Addict Med Ther Sci 6(1): 016-020. DOI: https://dx.doi.org/10.17352/2455-3484.000031 